\title{
sciendo CONTEMPORARY COMPUTER SUPPORT DESIGN SOLUTIONS FOR INDUSTRIAL INFRASTRUCTURE
}

doi:10.2478/mape-2018-0056

Date of submission of the article to the Editor: 04/2018

Date of acceptance of the article by the Editor: 07/2018

MAPE 2018, volume 1, issue 1, pp. 443-449

\author{
Dr inż. Waldemar Kostrzewa \\ Mgr inż. Elwira Kałkowska \\ Dr hab. inż. Krzysztof Nozdrzykowski, prof. AM \\ Maritime University of Szczecin, Poland
}

\begin{abstract}
This article is a proposition to use modern CAD (Computer Aided Design) solutions to design industrial infrastructure, and show many benefits of their practical use, avoiding numerously mistakes while the investment process, at the same time increasing the quality of created products during reducing the costs associated with their production. The paper proposes a method of stocktaking of the current state and methods of spatial layout analysis of planned investment using smart databases to configure the individual manufacture slots. The method of material flow analysis in the virtual model of the production line was presented, tools for the analysis of the production line were indicated, especially focused on collision identification, work schedule creation and parametric analysis of designed installations.
\end{abstract}

Key words: Design, CAD, technical documentation, 3D modeling, planning, optimization, production line, production processes, visualization.

\section{INTRODUCTION}

For many years, the primary tool used by computer-aided design was $2 \mathrm{D}$ technology, facilitating the work of designers in many industries. The ease of implementation was due to direct reference to traditional working methods, by replacing traditional drawing boards with flat vector graphics applications. By facilitating and accelerating change, using repetitive elements, increasing the accuracy of objects drawn, and automating dimensioning activities, these applications have significantly modernized the design process. However, this kind of work was limited to the necessity of continuous conversion of the spatial concept of the designer to a two-dimensional writing system. Unfortunately, the milieu of $2 \mathrm{D}$ technical documentation does not allow the creation of complex interrelations of particular parts to assemblies, taking into account all parametric and kinematic relationships, checking possible collisions between cooperating parts and comprehensive simulation analysis, based only on the experience of the designer.

$2 \mathrm{D}$ technology significantly reduces the growth of productivity what may cause a delay in the timely introduction of the product on the market. Obsolete design techniques force at the same time to manually perform many tasks, such as the implementation of traditional methods to inventory industrial objects using measuring tape or laser rangefinders. The lack of possibility of spatial analysis in terms of optimal use and deployment of machinery and equipment in production departments, when space is being used (for example with minimum transport widths), significantly reduces the possibility of a potential change in production. Very unlikely is also lack of simulations of planned investments possibilities in terms of many factors, such as bad lighting, ventilation, noise, vibration, etc. Using only 2D tools reduces the communication between project participants, reduces team efficiency, causing delays, changes in design, and often exceeds budget. The basis of use of tools supporting many 
industrial infrastructure design processes is a comprehensive implementation of 3D models, accurately imitating the actual state of created objects (including machines and devices).

\section{INVENTORY OF THE CURRENT STATE OF PLANNED INVESTMENT}

Inventory of the current state of the examined object often has a decisive influence on the analysis of the production line layout. In practice, there is often a situation in which the technical condition of equipment, installations and even the whole infrastructure are worn out as a result of exploitation and their technical documentation is incomplete, incompatible with the current state or does not exist. In such cases, the only solution is stocktaking, the comprehensive documentation of infrastructure with a description of the technical state of each device (Gawlik et al., 2013). As long as the technical condition of the equipment is verified on the basis of work parameters in relation to the technical documentation, the description of the surveyed space is mostly based on the adaptation of existing 2D layout documentation and spatial laser scans.

The basic information is point cloud (Fig. 1) which is the collection of data, that constitutes the basis for the spatial representation of the scanned object. The resulting model, often located in the context of existing 2D layout documentation, is a source for collision analysis with a designed model by designer.

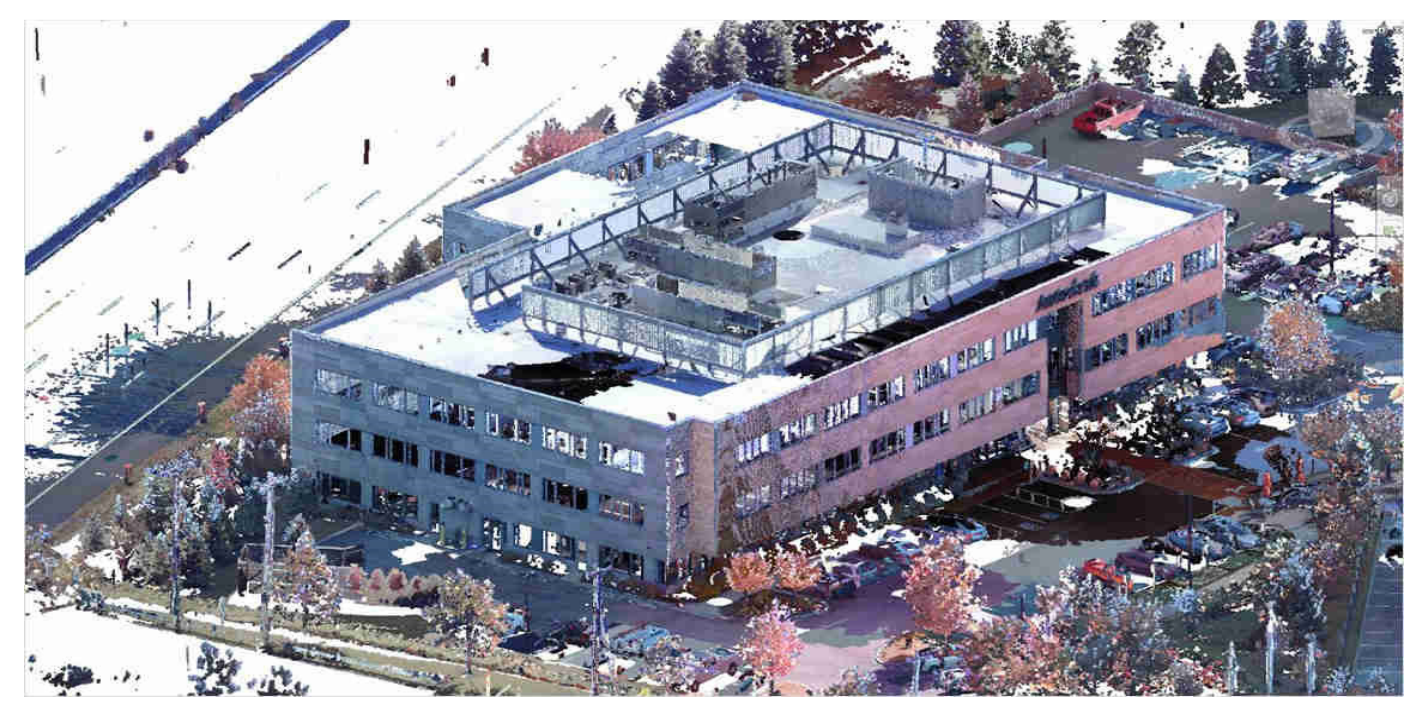

Fig. 1. Point cloud - a fragment of a scanned object

\section{USE OF DATABASES TO CONFIGURE THE PRODUCTION SLOTS}

After an inventory of the then current state of the object to the construction of individual positions production line, are used the database updated with their own newly created objects. They are a collection of elements of industrial infrastructure, such as machines, storage, transportation or architectural elements used in the design of individual production slots (Fig. 1). Databases containing component libraries are divided into local and cloud. Local libraries are integrated with the software package, while cloud libraries may be available online through "cloud" services, which greatly facilitates and accelerates communication between team members and manufacturers of ready-made production slot components (Jucha and Nowacki, 2016). In the case of systematic use of elements in cloud libraries, it is possible to store them in local resources, which results in no delay in the design work. Local libraries, except resources provided by the software manufacturer, may also be powered by their own models designed for example in the design department of the enterprise. 


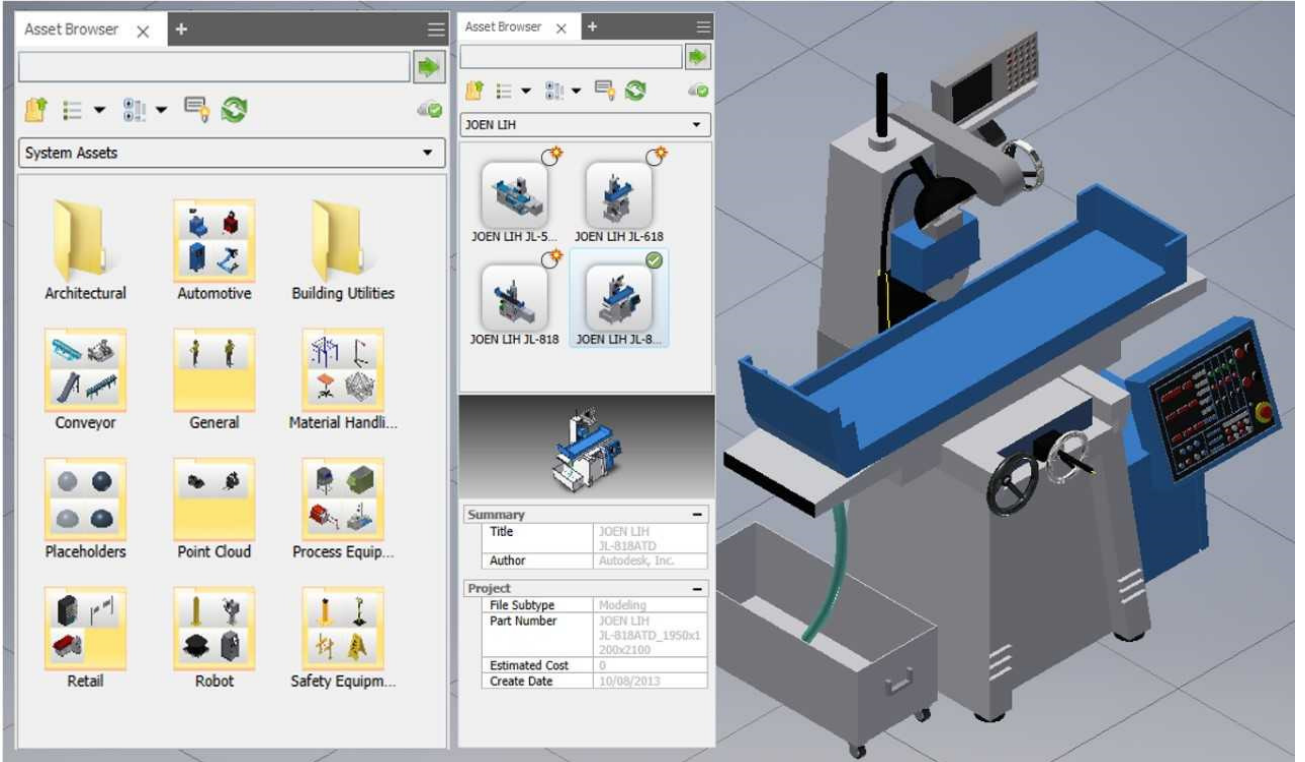

Fig. 2. General view of the system library and elements for building CNC machine stations

Application ready-made intelligent library items with thanks to connection's points and autodiscovery of mechanisms binding allows to specify the operating range of individual devices, allowing to optimize communication volumes with respect to OSHA (occupational safety and health) rules, minimizing the risk of errors, and significantly accelerating workflows (Fig. 2).

\section{CONSTRUCTION OF THE PRODUCTION LINE}

By automatically synchronizing the 2D layout to the 3D layout and vice versa, building individual production slots, and as a result, the entire production line can alternately take place in both environments. The 3D environment allows to detect any physical obstacles that are difficult to grasp during designing in a 2D layout environment and to eliminate them at the design stage (Fig. 3). Both environments use the same libraries, giving the ability on 2D plan to preview of a selected production line element that is a flat representation of the $3 \mathrm{D}$ model (Caggiano and Teti, 2018).
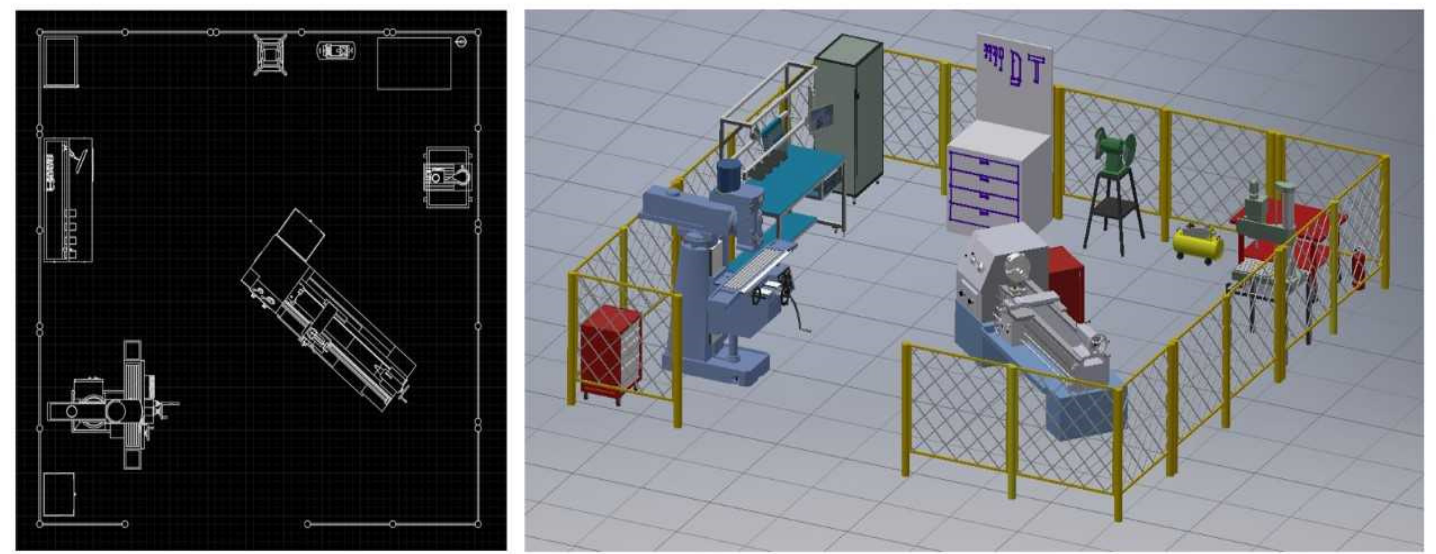

Fig. 3. Designed machining station $-2 \mathrm{D}$ view and 3D visualization

The built this way production line can be analyzed and optimized for material flow, production costs, and energy consumption. 


\section{OPTIMIZATION OF THE PRODUCTION LINE}

Before optimizing the previously designed production line, it is necessary to determine the course of the production process, as well as to assign the types of operations performed and the parameters to specific sockets, that characterize the technological process performed in a socket (Shariatzadeh et al., 2012). An analysis of the production line in terms of transport cost, total cost of production, and analysis of defined routes is possible after defining all parameters characterizing the production line, the road and direction the product must overcome.

Optimization of the technological line layout is made by changing the location of the individual production sockets and their components, taking into account the flow direction of the material.

Analysis of the results allows effective positioning of the individual production sockets, which in turn will reduce the time of material transportation in a cycle. Changes in means of transport will affect the reduction of inter-company transport and consequently the reduction of its costs, thus reducing the total cost of production.

\section{ANALYSIS OF THE PRODUCTION LINE}

One of the basic tools for analyzing the layout of the production line are mechanisms for detecting spatial limitations and interfering with each other devices, which allows us to evaluate the spatial functionality of the project at an early stage of the investment (Janczarek, 2011). In the integrated model of the production hall, the use of virtual walking gives the opportunity to move across the entire virtual layout with the ability to generate omnidirectional panorama, any zoom, rotate, and climb stairs, while setting a specific height (for example, employee height, forklift height). This type of facility inspection allows for an accurate overview of the location of each production machine and the installation process (Ministerstwo Infrastruktury i Budownictwa, 2016). Facing elements of the production hall doubtful concerning their proper placement or size, there is a possibility of measurement and then give a note in the form of a comment the person coordinating the project (Fig. 4).

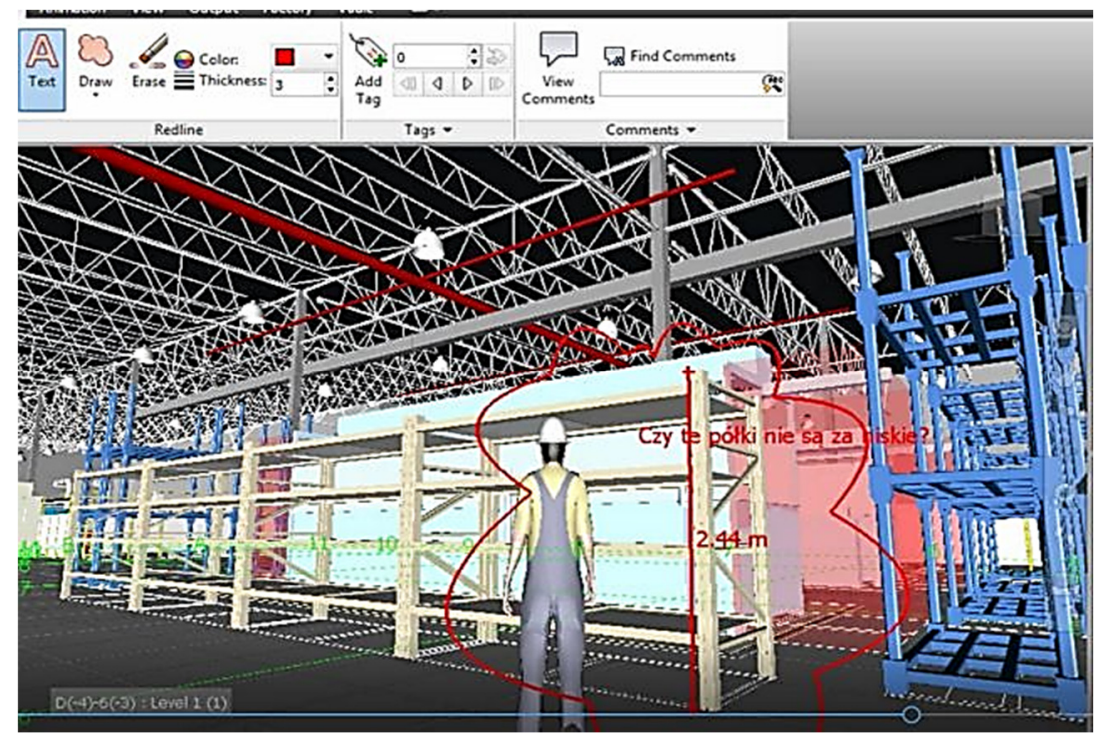

Fig. 4. View of the measurement and comment

To analyze spatial limits and inter-object conflicts collision detection tools are used between any investment element and the selected product groups included in the analysis (for example, collision analysis between piping and building construction).

The results of detected collisions are marked on the works' schedule and generated in the form of a status report, which greatly simplifies the management of error correction (Fig. 5). 


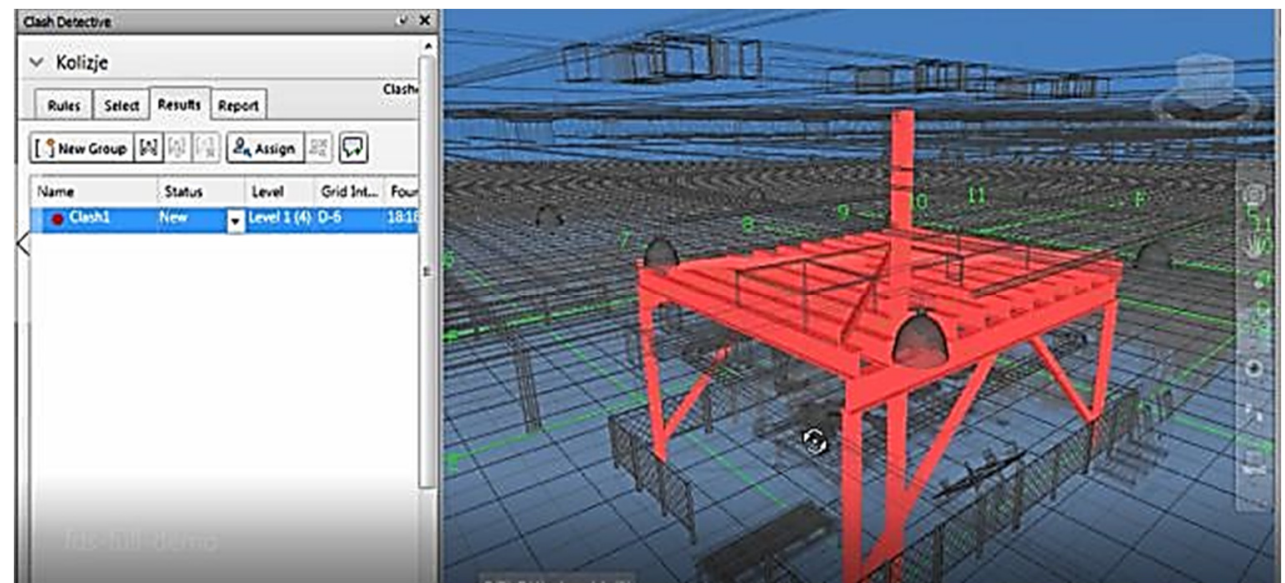

Fig. 5. Detected collision between the production place and the hall construction element

In the design process it is very important to plan the work to be done at a certain time by setting up a suitable work schedule. Based on this, a simulation of the implementation process is created, which allows to verification of the advancement and the possibility of quick reaction to possible deviations from the planned plan (Sydor, 2016, Tomana) . Created this way the information base is available to all participants in the project, resulting in the maximization of the available resources. This timetable is also the basis for building simulations, and then reconstruct the stages of investment in the form of animation (Fig. 6).

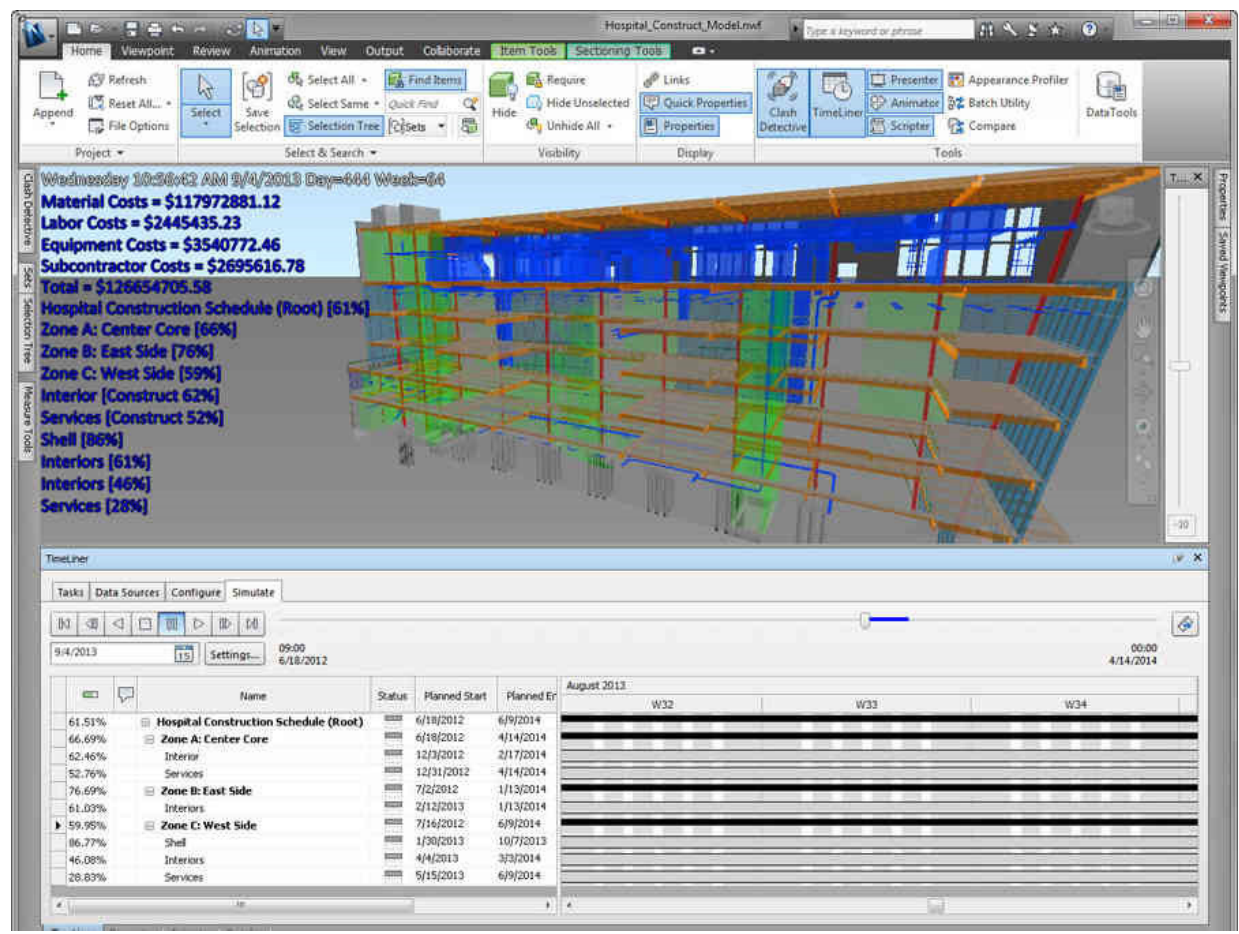

Fig. 6. Project validation using Navisworks Manage

A problematic issue is the selection of parameters of newly formed systems, which appear especially in non-typical objects of complex geometry and large cubature. For analysis of the efficiency of the planned installations, is used Computational Fluid Dynamics (CFD) (Paul, 2015, Penkała and Gorecki, 2008), which can be used to analyze digital flows (for example, air conditioning and ventilation) and thermal phenomena (for example, heating) (Fig. 7). 


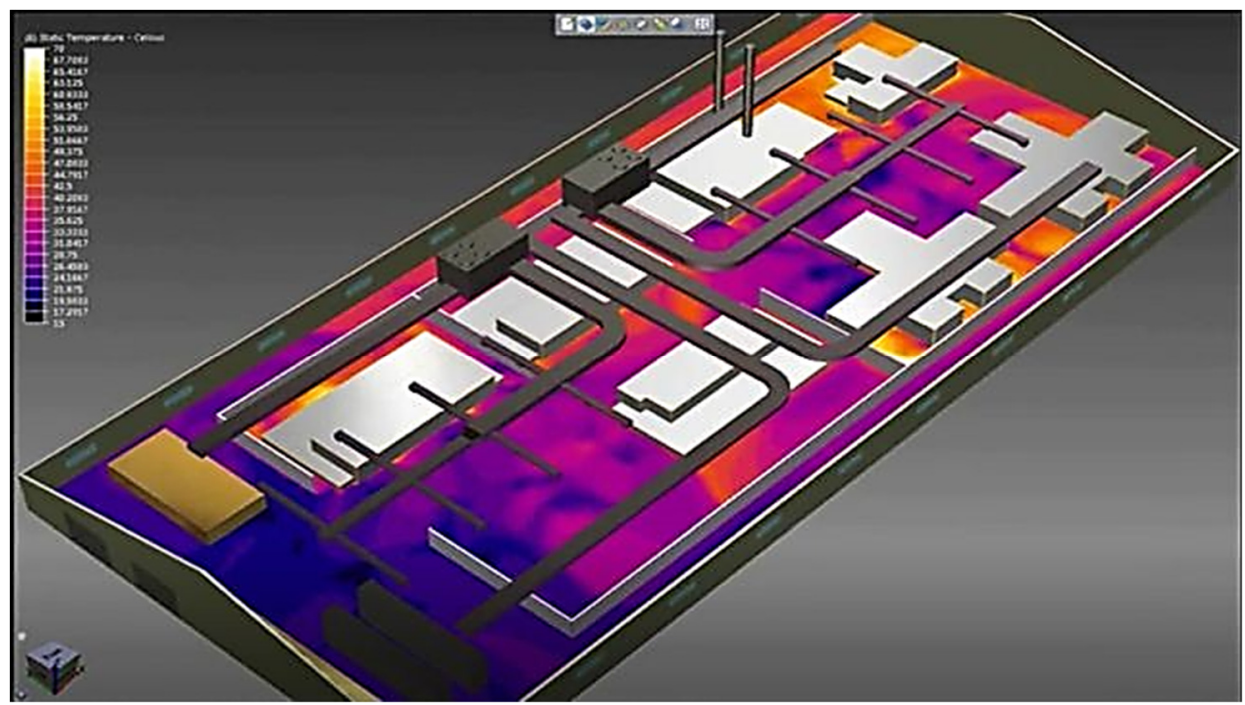

Fig. 7. Thermal analysis of the production hall

Efficient operation of the using installations is a key element, which determines the comfort of the employees (for example, proper pressure, speed and appropriate flow of air in the ventilation system).

Additional support tools and improving decision-making processes are photorealistic 3D rendering and interactive animations to facilitate understanding of design concepts.

\section{CONCLUSION}

The use of modern computer-aided design solutions presented in this paper, allows to achieve many benefits at the design stage, and the implementation of investments related to industrial infrastructure.

With available inventory tools for the state of the existing industrial infrastructure, compensating for missing or incomplete technical documentation, the fastest and most accurate method is $3 \mathrm{D}$ scanning technology that verifies that the planned modernization takes place without collision (for example, installing new machines).

Intelligent databases powered by native models are used to build individual production line, enabling connection points to define complex kinematic constraints of interdependent mechanisms. This allows to specify the operating range of each device (Sokołowski, 2007).

Modern tools for analyzing and optimizing production processes enable the elaboration of a dedicated solution for the project, thus providing significant support for constructors and designers (Więznowski et al., 2007). This enables the efficient placement of the individual production sockets, thus reducing the time of transport and, consequently, reducing the total cost of production.

The mechanisms of the analysis of the production line, detecting spatial limitations, allow to evaluate the functionality of an object. In addition, the presented tools organize the design data and revolutionize the attitude to information management in the project, while supporting work safety during the investment process. The tool presented in the paper, using CFD modeling, analyze the parameters of the planned installations, thus improving the comfort of future employees (Jasionowski and Kostrzewa, 2017).

Using innovative design methods allows to achieve a number of benefits in the design process, while enhancing the quality of products and avoiding mistakes during the investment process. There is a reduction in costs throughout the project cycle, the implementation of the investment and its subsequent functioning. With these tools, crossindustry design collaboration improves, and the work is done more efficiently. 


\section{REFERENCES}

Caggiano, A. and Teti, R. (2018). Digital factory technologies for robotic automation and enhanced manufacturing cell design, Vol. 5, issue 1, Article number UNSP 1426676.

Gawlik, J., Plichta, J. and Świć, A. (2013). Procesy produkcyjne. Polskie Wydawnictwo Ekonomiczne. Postępy Nauki i Techniki nr 4.

Janczarek, M. (2011). Zarządzanie procesami produkcyjnymi w przedsiębiorstwie. Lublin: Lubelskie Wydawnictwo Naukowe.

Jasionowski, R. and Kostrzewa, W. (2017). Optimisation of liquid flow in cavitation tunnel using CFD method. Vol. 15, article 07011.

Jucha, S. and Nowacki, K. (2016). Optymalizacja procesów produkcyjnych za pomocą narzędzi cyfrowych. Polskie Towarzystwo Zarządzania Produkcją, [online] Available at: www.ptzp.org.pl.

Ministerstwo Infrastruktury i Budownictwa, (2016). Ekspertyza dotycząca możliwości wdrożenia metodyki BIM w Polsce. Warszawa, [online] Available at: http://mib.gov.pl/.

Paul, E. (2015). Integracja: Projekt BIM, Inteligentny Budynek. [online] Available at: www.inteligentnybudynek.eu.

Penkała, P. and Gorecki, T. (2008). Modelowanie bryłowe i powierzchniowe w systemach procesach wytwarzania. Kraków: Politechnika Krakowska.

Shariatzadeh, N., Sivard, G. and Chen, D. (2012). Software Evaluation Criteria for Rapid Factory Layout Planning. Design and Simulation, Vol. 3, pages 299-304.

Sokołowski, P. (2007). Po prostu Inventor. [online] Available at: http://autodesk-inventorpl.typepad.com.

Sydor, M. (2016). Wprowadzenie do CAD. Podstawy komputerowego wspomagania.

Tomana, A. (2016). BIM Innowacyjna technologia w budownictwie. Kraków; PWB Media.

Więznowski, A., Sosnowski, M. and Szlachetka, P. (2007). Analiza i optymalizacja procesów produkcyjnych i usług. Wrocław: Wydawnictwo Akademii Ekonomicznej im. Oskara Langego we Wrocławiu. 